\title{
RECRUITING RECENT GRADUATES TO WORK AT AGRICULTURAL ENTERPRISES: SIBERIAN REGION CASE STUDY
}

\author{
Andrey Babenko ${ }^{1}$, Leonid Mukhin ${ }^{2}$ \\ ${ }^{1}$ Department of Agricultural Biology, Tomsk State University, 36 Lenin Ave., Tomsk, Russia, 634050 \\ e-mail: andrey.babenko.56@mail.ru \\ ${ }^{2}$ Department of Employment and Practice, Tomsk State University, 36 Lenin Ave., Tomsk, Russia, 634050 \\ e-mail:leonmukhin@gmail.com
}

\begin{abstract}
The authors present the results of the analysis of the employment of graduates of agricultural specialties in the Siberian Federal District of the Russian Federation. In the Siberian Federal District, more than 20 universities are engaged in the training of specialists in agriculture. The universities pay special attention to the employment of their graduates and often have their own programs of graduates' employment.

The article is devoted to discussing the reasons why the graduates consider the work in the rural area to be unattractive (low standards of living conditions compared with town, lack of quality education for children and possibilities for professional development, etc.) The necessity of realization of the state strategy intended to support graduates of agricultural specialties is grounded, including assigning the status of civil servants to social workers in rural areas and attracting successful entrepreneurs to the village and creating conditions for the development of the entrepreneurial environment.
\end{abstract}

Corresponding author: Andrey Babenko, andrey.babenko.56@mail.ru

Keywords: employment programs, agricultural enterprises, Siberian Federal District.

(JEL Code: J 21)

\section{INTRODUCTION}

All Russian universities pay special attention to the employment of their graduates: contacts are established with the leading industrial enterprises, new employers are being sought, targeted educational programs are being formed, etc. Graduates of agricultural training areas that will work in rural areas, of course, are given special attention.

A long-lasting rural youth drain trend in Russia has resulted in acute shortage in professionals in agricultural business. There are programs aimed at recruiting young professionals to work at agricultural enterprises in a number of rural regions in Russia. To cope with this situation and inspire young professionals to move to rural regions the program "Young professionals in the rural area" was introduced. Within the program young professionals are given lump sum cash payment, soft real estate purchase loan and subsidy to cover travel expenses to get to the place of their employment.

The government allowance intended to support young professionals is not taxed. For a person to take part in this social program they are to work for the enterprise not less than 5 years after getting the allowance. Besides, their professional activity should be related to their specialty. For the time being the program is intended to continue until 2020. In accordance with the federal law, the estate purchase loans are given at the expense of allocating subsidies to federal subjects of the Russian Federation from the federal budget. The subsidies are allocated in accordance with the program of rural area development.

Universities have their own programs of graduates' employment. In particular, Tomsk State University (TSU) has a department of support for those graduates who have difficulties with employment. A great number of vacant positions in rural areas are offered; as a result, about $70 \%$ of TSU graduates work within specialty.

\section{MATERIALS AND METHODS}

We used the official data presented on the website of the Ministry of Education and Science (www.graduate.edu.ru) to analyze the employment of university graduates. The research of vacancies and career opportunities for young specialists was carried out according to the All-Russian vacancy database of the Employment Service (Rostrud), which is available on the website trudvsem.ru. We also surveyed the graduates of agricultural specialties who graduated from the TSU in 2007-2016. 


\section{RESULTS AND DISCUSSION}

The largest institute at Tomsk State University, the institute of biology, ecology, soil science, agriculture and forestry, annually produces about 220 young specialists in various areas of training. About $35 \%$ of them continue to take master or postgraduate courses, $15-17 \%$ graduates do not apply for a job (because of doing military service, maternity leave or some other reasons), all the rest are employed by the organizations, institutions, private companies in Tomsk and nearby towns. Only some graduates ( 7 people in 2015, 5 - in 2016) go to work in rural areas, as a rule, to the places they are from.

The exchange of information with colleagues from other universities of the Siberian Federal District, own statistical studies suggest that a similar situation develops with the employment of graduates in other Siberian universities.

In Siberia, 22 universities are engaged in the training of specialists for agriculture. In 2014 and 2015, 3231 and 3,290 specialists with a higher education of all levels (bachelors, specialists, masters) were trained in the group of specialties "Agriculture, Forestry and Fisheries" in 8 universities in the Siberian Federal District (Table 1). The share of graduates of these specialties in the number of the other universities' graduates is less than 30 people per year. We studied the statistics of employment of the graduates specialising in agriculture, for example, agronomy, including agro engineering and agro-chemistry, animal science, animal medicine, etc. In 2017, the Ministry of Education published the monitoring of the employment of graduates in 2015. For comparison, Table 1 provides the information on graduates in 2014-2015. It should be noted that the percentage of employed graduates changes insignificantly from year to year.

Table 1 Number of graduates in Siberian universities in agricultural specialties

\begin{tabular}{|c|c|c|c|}
\hline \multirow{2}{*}{ University } & \multicolumn{2}{|l|}{ Year } & \multirow{2}{*}{$\begin{array}{l}\text { Percentage } \\
\text { of employed } \\
\text { graduates, \% }\end{array}$} \\
\hline & 2014 & 2015 & \\
\hline Burjat State Agricultural University & 268 & 370 & 76 \\
\hline Gorno-Altaisk State University & 50 & 44 & 78 \\
\hline Irkutsk State Agricultural University & 306 & 436 & 65 \\
\hline $\begin{array}{l}\text { Krasnoyarsk State Agricultural Univer- } \\
\text { sity }\end{array}$ & 1084 & 902 & 72 \\
\hline Kemerovo State Agricultural Institute & 359 & 375 & 72 \\
\hline $\begin{array}{l}\text { Novosibirsk State Agricultural Univer- } \\
\text { sity }\end{array}$ & 650 & 565 & 77 \\
\hline Omsk State Agricultural University & 445 & 479 & 80 \\
\hline Tyva State University & 69 & 119 & 78 \\
\hline Total graduates: & 3231 & 3290 & 73 \\
\hline
\end{tabular}

The data on the employment of graduates of universities are available on the website of the Ministry of Education and Science www.graduate.edu.ru. The share of employment of graduates of the agricultural profile is $72.6 \%$, which is slightly lower than the average for other specialties, which is about $75 \%$.
Unfortunately, there are no available data on how many young professionals are employed each year in rural areas, it can be assumed that their number is much less.

For the time being, the regions in Siberia offer 212 vacant positions for the agronomists, about 40 of them include employerrented housing. The salary is $12,000-25,000$ rubles (individually - up to 40,000 rub.) For the sake of fairness, it should be noted that the enterprise inviting a young specialist often additionally guarantees him payment of rented housing, which is from 5 to 15 thousand rubles. At the same time, in the Krasnodar Territory, out of the offered 75 vacant places, the majority designates a salary of 20,000 rubles, and more than a third of vacancies here presume a salary of 40,000 rubles. These are the data from the all-Russian vacancy database (trudvsem.ru).

Unlike most large industrial enterprises, even large agroholdings do not conduct targeted mass recruitment of young professionals and often do not even have their own sites on the Internet. When a need for such workers arises, they publish vacancies for example on trudvsem.ru or hh.ru. More often, they apply directly to the relevant educational institutions of the region. At the time of the preparation of the article, it was not possible to find any agro-holding site on the Internet, on which there was a description of the personnel policy for attracting university graduates.

The reasons why university graduates do not seek to leave for work in the rural area are as follows:

- rural settlements fail to provide the same comfortable living conditions as in the city. Even young people who came to study in the city from the countryside do not want to return home, having met the amenities of city life;

- low assessment of the prospects for personal growth, prospects for career development in agriculture. Despite the numerous programs of "rural development" and the rise in agriculture, work in rural areas is assessed as not very promising;

- low level of wages in agricultural enterprises, especially in regions with unfavourable climate, which include all regions of Siberia.

While preparing for the 2006 All-Russian Agricultural Census a study was conducted that showed the most significant reasons for the lack of aspiration of people to work in the countryside:

- low quality of workplaces, lack of modern equipment, irregular working conditions;

- lack of public transport;

- poor quality of medical care, lack of quality education for children;

- lack of opportunities for quality rest;

- lack of professional and career prospects (the most crucial indicator in terms of stability in rural areas) [PETRIKOV et.al, 2005].

Thus, the unpopularity of agricultural enterprises, as employment opportunities for university graduates, is explained by the low social prestige of life in rural areas and the ineffectiveness of working conditions. In various regions of Russia there were regional programs for attracting young specialists to the countryside. 
For example, in the Nizhny Novgorod region, graduates of universities - doctors and teachers were allocated funds for the purchase or construction of a separate cottage. In the Ryazan region were provided lifting in the amount of 86,000 rubles. Such programs have been adopted in the regions of the Siberian Federal District. For example, within the framework of the programme "Staffing of the AIC of the Krasnoyarsk Territory", "Providing affordable housing for young professionals in the countryside". Students in the period of study make an agreement with the farm, where they will come to work after receiving the diploma. According to the agreement, their salary should be at least 15,000 rubles and if the young family chooses to stay in the village, the local budget will finance $70 \%$ of the housing cost. However, sometimes the conditions of the programs do not allow anyone to participate in them, for example, the requirement to immediately pay the remaining $30 \%$ of the cost of housing. As a rule, young families do not have such means [MUKHIN, ABRAMOV, 2011].

Unfortunately, numerous agricultural development programs, declared, including at the highest level, do not give the desired result due to the lack of a systematic approach.

A state strategy is needed to create federal agrocorporations using the latest achievements of agricultural science and practice. In connection with this, some innovations will certainly be useful:

1. Assigning the status of civil servants to social workers in rural areas. Doctors, teachers in schools, public transport drivers, other specialists, provided they achieve a certain length of specialty, work in rural areas receive such a status. Such innovation will significantly increase the prestige of work in rural areas and, most importantly, improve the quality of the services provided. Young specialists - graduates of universities of relevant specialties will receive an additional incentive to find employment in rural settlements.

2. Attracting successful entrepreneurs to the village and creating conditions for the development of the entrepreneurial environment [LAVRUKHINA, 2011]. Working out of special programs of grants, loans, state support of credits for those who decided to develop their business in rural areas. Special conditions should be created for entrepreneurs creating new enterprises within the framework of state agricultural holdings.

Attracting successful entrepreneurs to create infrastructure in rural areas is a fundamental issue of future reform. Unfortunately, the training of entrepreneurs in universities is limited to information about the registration of an enterprise, the opening of a bank account and other formalities. "Entrepreneurship" no one teaches and does not know how to teach. It is extremely rare to train or educate students working entrepreneurs who are able to demonstrate and broadcast the necessary business and personal "entrepreneurial" qualities.

Training of people with a pronounced entrepreneurial vein should become a distinctive feature of training on the specialty "Rural, Forestry and Fisheries". Together with the introduction of special programmes to support entrepreneurship in the countryside, this will give a powerful impetus to the development of agriculture.

\section{REFERENCES}

Lavrukhina E. A. (2011): Paradoxes of agrarian colleges graduates job placement, Higher education in Russia 2011; № 2:126 - 130.

Petrikov A.V., Jabnykh R.G., Uzun V.J., Korbut L.S., Rodionova G.A., Platonova L.S., Zinchenko A.P., Petukhova A.V., Baikov V.E., Ephanova O.A., Lavrukhina E.A., Epikhina A.V. (2005): All-Russian agricultural census: problems, methodology, recommendations, Encyclopedia of Russian villages, Moscow, 2005 ISBN: 5-88367-055-5

Abramov O.K., Mukhin L.N. (2015): Staffing of the Innovative Economy. In: Soldatova AN, Minkova SL, editors. INNOVATION-2015, Proceedings of the XI International School-Conference of students, graduate students and young scientists; 2015 May 21-23; Tomsk. Publishing house «STT», 2015: 595-600.

\section{Internet sources:}

www.graduate.edu.ru [read October 22th, 2017]

www. trudvsem.ru [read December 10th, 2017] 
